\title{
Political Institutions, Punctuated Equilibrium Theory and Policy Disasters Working Paper
}

\author{
E.J. Fagan \\ Assistant Professor \\ Department of Political Science \\ University of Illinois at Chicago \\ ejfagan@uic.edu
}

\begin{abstract}
This paper develops a theory of the relationship between policy disasters and political institutions. Policy disasters, defined as avoidable, unintended extreme negative policy outcomes, are important political and historical events above that receive relatively little attention from political scientists and scholars of public policy. Using the predictions of punctuated equilibrium theory, I argue that systems with higher error accumulation will experience more policy disasters. These disasters will take two forms: disasters caused by policymaking negligence and disasters caused by policymaking mistakes. Systems with more veto players and weaker information flows will experience more disasters, but information flows will have a stronger impact than veto players. I test this theory using data on financial crises and natural and technological disasters across seventy countries over sixty years. I find strong evidence that systems with weaker information flows and more veto players tend to have greater disaster risk.
\end{abstract}


Policy disasters are seminal events in a country's political history. Famines, infrastructure collapses, financial crises, and other outcomes resulting from egregious decisions by policymakers create enormous human and economic damage to a society. They often lead to catastrophic consequences not only for directly-affected people, but also for the governments and elites in power (Cho and Jung 2019; Treisman 2020). Policy disasters also often lead to interesting inflection points in public policy by creating major focusing events that catalyze large policy punctuations (Albright 2011; May, Sapotichne, and Workman 2009; Nohrstedt 2008; Nohrstedt and Weible 2010). The narratives that develop around the causes of policy disasters shape policy agendas (Baumgartner and Jones 1993; D. A. Stone 1989). While they are rare events, they are substantively important to our understanding of policy processes.

Yet, the causes of policy disasters remain largely unstudied by political scientists. They are often treated as exogenous shocks, rather than preventable or foreseeable consequences of public policy decisions (Crow et al. 2018; Williams 2009). When examined as a generalized matter, social scientists tend to treat policy disasters an independent variable with some impact on policy learning, politics, or some other dependent variable (Cho and Jung 2019; May, Sapotichne, and Workman 2009; Treisman 2020). Other disciplines tend to focus on the causes of specific categories of disasters, rather than a generalized theory of policy disasters (for example, see: Barredo 2009; Jonkman and Kelman 2005; Petley 2012; Reinhart and Rogoff 2011). However, if policy disasters are largely driven by an underlying political process, rather than subject-specific factors such as geography or levels of development, a general theory of policy disasters is necessary to explain their variation.

This paper develops a theory of policy disasters and governing systems rooted in Punctuated Equilibrium Theory (PET). I theorize that disasters are more likely to occur when 
errors accumulate. For example, policymakers who fail to maintain and update a system of dikes and levees in response to changing climate patterns risk causing a massive flood. Thus, higherfriction systems will have more disasters. I further argue that two processes in high-friction policymaking systems lead to disasters: disasters caused by negligence and disasters caused by policymaking mistakes. Negligent disasters occur when policymakers ignore a problem, allow errors to accumulate, and a policy problem spirals out of control into a much more serious problem. Disasters by mistake occurs when policymakers overreact to a policy problem, causing errors to accumulate after a policy change. Systems with more veto players and weaker information processing have greater friction, leading to great disaster risk. Higher veto players increase disaster risk by increasing the risk of negligence. Lower information processing capability increases the risk of disaster by negligence by decreasing problem detection and definition. Furthermore, low information processing will increase the risk of overreaction by decreasing a system's ability to correctly judge the appropriate intensity of a policy response.

Finally, the paper tests its theory of policy disasters using a large-n study of two independent datasets of disasters over sixty years. I examine risk of financial crises in 70 countries from 1950-2010 and risk of natural and technological disasters in 69 countries from 1950-2016. I find that higher-friction systems, such as electoral autocracies and electoral democracies, have high disaster risk. Closed autocracies, where veto players and information flows are constrained, have moderate risk of disasters. Liberal democracies have the lowest risk of disasters. Furthermore, an analysis of individual components of information flows and veto players suggests that improved information flows have a much stronger impact on disaster risk than veto players. More unequal societies, systems with more dominant executives, more federalized systems and systems with media or civil society repression tend to have greater 
disaster risk. I conclude that strong information flows have a strong impact on disaster risk, but further research is needed to determine the impact of veto players.

\section{A Punctuated Equilibrium Theory of Policy Disasters}

Scholars use several different terms to conceptualize intense policy failures. Various scholars examine policy fiascos, defined as perceived policy failures where the decision-makers are blamed for outcomes (Treisman 2020). Bovens and 't Hart (2016) distinguish between a policy failure, a policy that does not achieve its intended outcome, from a policy fiasco, where a perceived policy failure results in blame placed upon the government. Tuchman (1985) uses the term 'follies' to refer to avoidable policy decisions that were seen as major errors in their own time. Dunleavy (1995) uses a similar definition to define policy disasters. Because I am interested in the policy outcomes resulting from poor policy decisions, rather than the political consequences of those decisions, I follow Tuchman and Dunleavy by defining a policy disaster as avoidable negative policy outcomes caused by either a failure to address a problem or major negative unforeseen consequence that significantly outweigh any positive benefits it provides.

Scholars have pointed to numerous causes of intense policy failures, fiascos, and disasters. Most of these theories are specific to the type of disaster, rather than generalized theories of policymaking error (Bovens and 't Hart 2016). The generalized theories fall into two groups. The first group explains the psychological mechanisms that cause decision-makers to choose poor policy alternatives. Myopic decision-makers often ignore the potential for policy environments to change over the long-term (Nair and Howlett 2017). Policy diffusion mechanisms can cause translation errors when a policy from one context is adopted to a separate

context (D. Stone 2017). Policymakers can fail to learn from past failures (Dunlop 2017; Dunlop, 
James, and Radaelli 2020). Governments can fail to identify the correct policy instruments to solve problems (McConnell 2016). Leaders with strong ideological conviction can fail to learn from their mistakes (Tuchman 1985). The second group explains policy failure as the result of poor incentives and political institutions. Ambitious partisans are often incentivized to "go big" on policy alternatives in order to further their careers (Dunleavy 1995). Unchecked executives with excessive power are prone to large mistakes (Jones, Epp, and Baumgartner 2019; Tuchman 1985). Unitary governments can quickly make policy changes at scale, allowing them to make large mistakes (Dunleavy 1995). Bureaucracies that are required to respond to political incentives can ignore the advice of experts (Dunleavy 1995). Overall, the theoretical landscape lacks a generalized theory of policy disasters at the micro and macro levels.

Punctuated equilibrium theory (PET) predicts that policymaking decisions will follow an error accumulation model (Jones and Baumgartner 2005). Policymakers have limited cognitive and organizational resources to devote to making decisions but are met with a near-infinite set of complex problems to solve at any given time. Because the demand for policymaking attention always exceeds the supply of cognitive resources to attend to problems, they must disproportionately process information. Thus, at any given time policymakers will ignore most issues and only devote attention to the most pressing issues. While they ignore an issue, errors accumulate. Subsystems struggle to adjust to new or changing problems, or policies grow out of line with public demands. Error accumulation eventually leads to increases in problem severity. Governments that can process information and make decisions more efficiently will detect these problems and act to solve them. PET refers to limitations in government decision-making capacity as friction. Low-friction governments will act more efficiently to solve problems, reducing error accumulation, while higher-friction governments will be slower to react. As 
friction increases, a system's pattern of policy change becomes more punctuated, alternating between periods of stasis and episodes of dramatic change (Fagan, Jones, and Wlezien 2017; Jones et al. 2009).

There are two broad types of friction: friction caused by formal and informal veto players and friction caused by information processing limitations (Jones and Baumgartner 2005). Veto players slow down policymaking by requiring more actors to prefer a policy solution to the status quo in order for a government to enact it (Jones et al. 2009; Tsebelis 2002). Formal institutions such as bicameral legislatures, supermajority requirements, strong courts and presidents that can check a legislature increase the number of institutions that must support a policy for it to be enacted and implemented (Jones et al. 2009). Fractionalized party systems can increase friction by making it more difficult to reach majority consensus (Fagan, Jones, and Wlezien 2017; Or 2019). Informal institutions such as powerful interest groups or media can also frustrate change (Baumgartner et al. 2009; Wolfe 2012). As the number of formal and informal veto players increase, friction increases.

The second source of friction is a function policymakers' ability to search for and process information. While all policymakers must disproportionately process information, some governments will be able to process it more efficiently than others. Decentralized governments will be able to involve more decision-makers, allowing it to serially process information (Jones 2001). Governments and societies with greater flows of information will be alerted to problems more quickly (Baumgartner and Jones 2015; Chan and Zhao 2016). Deliberative processes, such as engagement with the media, experts or civil society, will require policymakers to engage with many policy alternatives that could be applied to a given problem. However, these processes can be blunted by unclear lines of accountability, such as "marble-cake" federalism, where voters, 
activities and other political actors struggle to direct information at the correct policymakers

(Fagan, Jones, and Wlezien 2017; Wlezien and Soroka 2012). Governments with poor information flows will make mistakes, implementing policy that either fails to meet its intended goals or causes other unintended problems (Fagan, Jones, and Wlezien 2017; Soroka and Wlezien 2010).

Punctuated equilibrium theory predicts that the distribution of policy change will always be leptokurtic. All governing systems produce a pattern of policy change that features more very large changes and very small changes than a normal distribution (Jones et al. 2009). It does not directly consider if those changes are good or bad for society. A large policy change could result in the establishment of a valuable program, eliminate a harmful one or avert a disaster just before it happens. It could also come in response to a serious disaster. For example, a major financial reform may follow a banking crisis. A severely leptokurtic distribution of change does not necessarily imply that a system experiences frequent serious policy disasters. PET only implies that the system struggles to process information efficiently, resulting in increased error accumulation. However, we can infer that higher error accumulation will increase the risk of disaster through two mechanisms: negligence and overreaction.

A neglected problem can cause a policy disaster. A system with a fatal flaw can potentially spiral out of control or cause a slow-moving disaster in the aggregate. Both poor information flows and veto players can cause policymakers to neglect to solve problems. When information flows are poor, policymakers will be less likely to be alerted to the severity or causes of a problem. Civil society and the media often play this role by sounding "fire alarms" for policymakers (Bevan and Rasmussen 2017; Boydstun 2013; McCubbins and Schwartz 1984; Wolfe 2012). Policymakers who are more exposed to public opinion may be more responsive to 
their preferences (Soroka and Wlezien 2010). If they allow a problem to continue without applying a solution to it, the cumulative effects of the accumulated errors could create a disaster, such as decades-long elevated gun violence rates in the United States. High errors also risk a feedback cycle where a problem rapidly spirals out of control, such as a banking crisis. Finally, a poorly maintained subsystem could be vulnerable to shocks that better-maintained systems are able to withstand.

Second, the largest policy punctuations risk creating sudden high error accumulation because of a bad policy decision. Policymakers could either overreact to a policy problem or make a mistake when choosing which policy alternative to apply to it. The largest error-prone punctuations are most likely to occur when policymakers face weak information flows. When information is weak, policymakers will struggle to calibrate the intensity of their response, the contours of the problem they are addressing, or which policy instruments are best suited to solving the problem. Dominant executives with few checks can pursue an idea that only makes sense in their gut, rather than ideas that survive deliberation and bargaining with other actors (Jones, Epp, and Baumgartner 2019). Finally, governments in unequal societies may ignore information from disempowered populations until they become very severe, such as growing addiction to opioids in communities with high rates of displaced or disabled workers. If the overreaction is locked in by some other process, it can create a policy bubble (Jones, Thomas, and Wolfe 2014; Maor 2014). For example, the overinvestment in policing and incarceration in the U.S. in the 1990s created a robust prison ecosystem that has proven difficult to unwind when crime went down (Jones, Thomas and Wolfe 2014).

Consider a hypothetical problem that demands some unidimensional policy response from policymakers. Policymakers can respond with a unidimensional policy response. Errors 
accumulate when the policy response is distant from need. When errors are higher, disaster risk increases. Figure 1 illustrates how a hypothetical low-friction government's response might compare to a high-friction's response to the same problem. A low-friction government frequently responds to changes in the policy problem by passing medium-sized policy changes. A highfriction government will allow errors to accumulate for longer before responding to the problem. Both governments tend to over-respond to problems, as positive feedback effects tend to create larger policy changes given a window of opportunity than is strictly necessary to solve the problem (Baumgartner and Jones 1993), and policy punctuations tend to be larger in high friction systems (Fagan, Jones and Wlezien 2017; Jones et al 2010). Errors accumulate as the distance between the need for the policy respond and the policy response undertaken by the government increases and thus the risk of disaster increases. Neglected problems are more likely to spiral into a disaster before policymakers respond by applying a solution to it. Low-friction systems go through some periods of increased risk of disaster, but more quickly mitigate that risk by responding to the problem with policy solutions. High-friction systems have larger punctuations because they are slower to respond to problems. When they do respond, their large punctuations risk overreacting to the problem, creating errors and increasing the risk of disaster. 
Figure 1: Model of Disaster Risk and Error Accumulation in High and Low Friction Governments

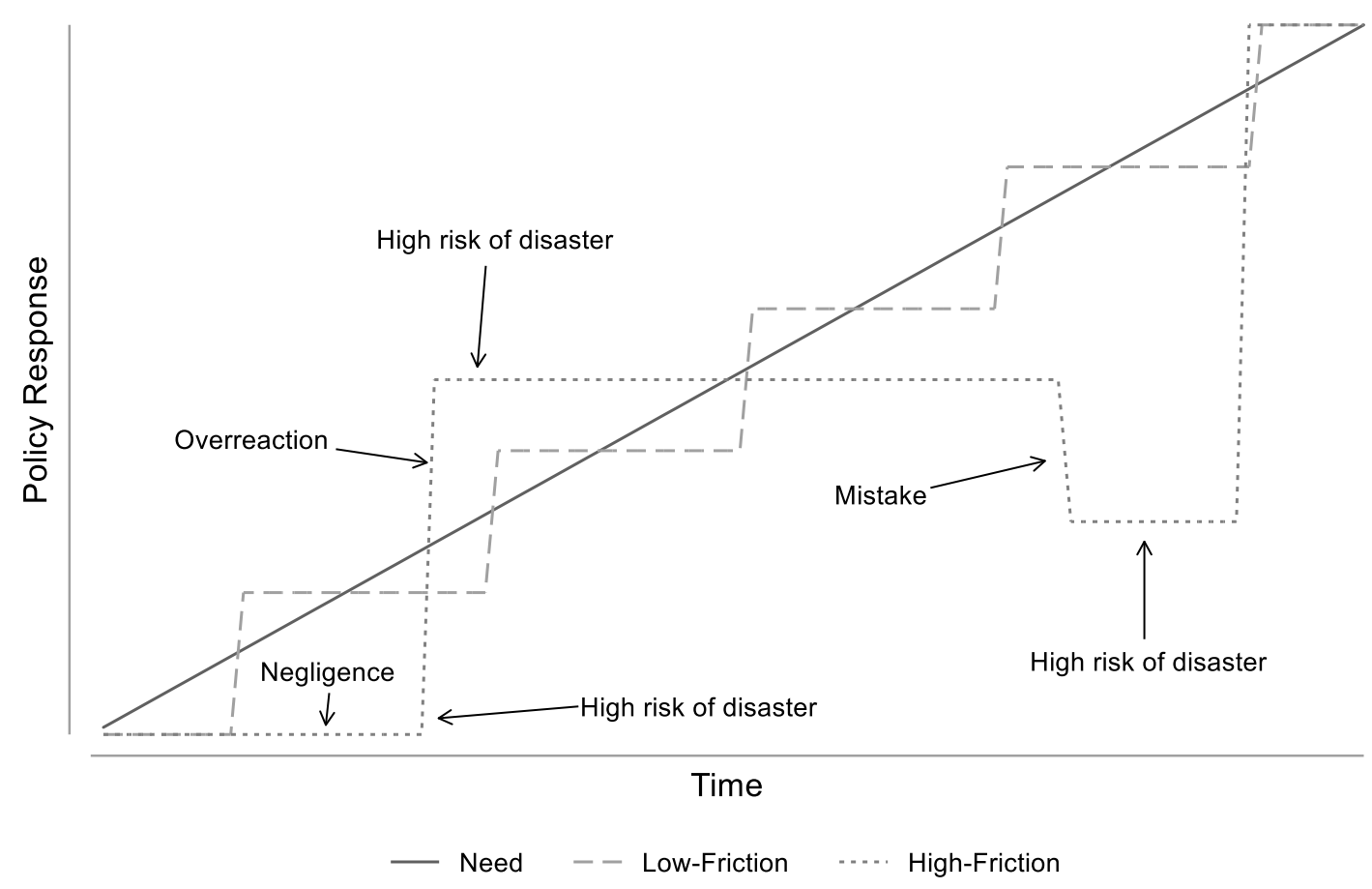

I derive two hypotheses from this theory:

Veto players hypothesis: systems with more veto players will have greater risk of policy disasters.

Information flows hypothesis: systems with poorer information flows will have a greater risk of policy disasters.

\section{Governing Systems and Policy Disasters}

We can test these hypotheses by leveraging well-established variation in information flows and veto players by political institutions. Systems that suppress or limit the flow of information and have many veto players will be more likely to experience disasters. In this section, I argue that liberal democracies will suffer the fewest disasters due to their uniquely strong information flows. Democracies with weak liberal institutions and autocracies with veto 
players will suffer the most. Closed autocracies, with their weak information flows but low veto points, will suffer from disasters at a higher rate than liberal democracies, but at a lower rate than the other two system types.

Both economists and political scientists have examined the relationship between democracy and policy outcomes. Democracies consistently perform better on human development indicators, such as health care, women's rights and education (Escudero 1981; McGuire 2013; Miller 2015; Sen 1981; Zweifel and Navia 2000). On economic growth, the results are more mixed. Olson (1993) argues that autocracies will encourage greater economic growth in order to extract greater resources from their country, while democracies tend to adopt policies favored by concentrated interests that tend to harm growth (see also Barro 1996). However, more recent results suggest that democracy increases growth considerably at all levels of development (Acemoglu et al. 2019; Tang and Tang 2018), although the effect may be negative in transitioning or young democracies due to weak trust in government and formal and informal institutions (Gerring et al. 2005; Keefer 2007). Both democracies and authoritarian countries with strong party systems tend to have higher growth (Bizzarro et al. 2018). These studies tend to theorize that electoral incentives are the cause of stronger democratic performance, although some also point to the importance of strong political institutions, civil society and information flows as secondary causes.

An emerging consensus in the punctuated equilibrium theory literature finds that authoritarian regimes tend to have a more punctuated pattern of policy changes. Efficient adaptive systems will produce a normal distribution of change (Fagan, Jones and Wlezien 2017). While all governments produce patterns of policy change significantly more leptokurtic than normal, authoritarian countries produce considerably more leptokurtic distributions than 
democracies (Chan and Fan 2020; Chan and Zhao 2016; Lam and Chan 2015). Countries that transitioned between democracy and authoritarianism are more efficient during periods of democratic rule, including Brazil (Baumgartner et al. 2017), Hong Kong (Or 2019), Hungary (Sebők and Berki 2018), Malta (Baumgartner et al. 2017), Russia (Baumgartner et al. 2017), and Turkey (Baumgartner et al. 2017; Bulut and Yildirim 2019). While all Chinese regions have highly punctuated distributions of policy change, regions where industrial workers organized labor disputes tend to have more efficient patterns of change (Chan and Zhao 2016). Scholars largely attribute this consistent finding to weak information flows in authoritarian countries (Jones, Baumgartner and Epp 2019; Lam and Chan 2015). Authoritarian governments nearly always suppress the media, civil society, scientists, opposition political parties and other sources of information flows to maintain power. As a result, they fail to detect problems and gather information on the best policy solutions when compared with liberal democracies.

There is also evidence that democratic systems with fewer veto points, stronger information flows, and greater deliberation produce a more efficient pattern of policy change. Federalized systems and systems with more political parties tend to be more punctuated (Fagan, Jones, and Wlezien 2017; Or 2019). Policy change in states with stronger governors tends to be more punctuated (Breunig and Koski 2009). Cities and school districts with more professionalized bureaucracies tend to be less punctuated (Park and Sapotichne 2019; Robinson 2004). Public agencies that engage in more deliberation with the public tend to be less punctuated (Epp 2018). Even in the private sector, corporations that are owned by their employees tend to be less punctuated (Epp 2018).

There is far less scholarship examining the relationship between policy disasters and governing systems. Policy disasters are a separate but related phenomenon from both 
performance and policy punctuations. Many governments or policies generate bad policy outcomes through poor performance, but poor performance rarely descends into disaster. Sen (1981) makes this observation in distinguishing between crop failures in India and China. Both poor nations were met with repeated agricultural crises, but only in China did they result in devastating famines. India suffered similar famines under colonial rule, but never since being established as a democracy. Indeed, Sen observes, while many democracies have dealt with crop failures or droughts, none has ever suffered a severe famine.

Policy punctuations are outlier events but observing that certain systems tend to have a more punctuated distribution of policy change tells us little about their risk of policy disasters. Policy punctuations imply a large magnitude, rather than a good or bad outcome. A large policy punctuation can itself avert disaster. We need to test the impact of policy disasters and governing systems directly, rather than assume that more punctuated patterns of policy regimes indicate that a system has more policy disasters.

Because information flows and veto players will vary by type of governing system, we can use variance in governing systems to examine potential causes of policy disasters. Table 1 shows these expectations in a $2 \times 2$ table. Liberal democracies with few veto players, such as a unitary parliamentary democracy, occupy the top-left quadrant. These systems should have low risks of all disasters. Liberal democracies with many veto players, such as bicameral systems and systems with a strong independent executive branch, occupy the bottom-left quadrant. These systems will have a moderate risk of disasters by negligence, but low risk of disasters by overreaction. Closed autocracies, with few veto players and constrained information flows, occupy the top-right quadrant. They will have moderate risk of disasters by negligence but high risk of disasters by overreaction. Finally, systems with elections but little civil society or liberal 
protections, such as weak or transitioning democracies or electoral autocracies, occupy the bottom-right quadrant. These systems will have high risk of disasters by negligence and moderate risk of overreactions.

Table 2: 2x2 Table of Regime Types

\begin{tabular}{|c|c|c|}
\hline & $\begin{array}{c}\text { High } \\
\text { Information Processing }\end{array}$ & $\begin{array}{c}\text { Low } \\
\text { Information Processing }\end{array}$ \\
\hline $\begin{array}{c}\text { Few Veto } \\
\text { Players }\end{array}$ & $\begin{array}{c}\text { Parliamentary liberal } \\
\text { democracies }\end{array}$ & Closed Autocracies \\
\hline $\begin{array}{c}\text { Many Veto } \\
\text { Players }\end{array}$ & $\begin{array}{c}\text { Liberal democracies with } \\
\text { many veto players }\end{array}$ & $\begin{array}{c}\text { Electoral democracies } \\
\text { and autocracies }\end{array}$ \\
\hline
\end{tabular}

Furthermore, we can expect that individual components of each of these regime types will lead to greater disaster risk. Systems of all kinds with more veto players should experience more policy disasters (Fagan, Jones, and Wlezien 2017; Jones et al. 2009). Parliamentary systems are much more efficient than presidential systems because many fewer actors need to come to consensus in order to change public policy (Fagan, Jones, and Wlezien 2017; Wlezien and Soroka 2012). Legislatures that hold independent power and legitimacy from the executive may frustrate decision-making. Finally, bicameral systems add friction by requiring two legislative bodies to come to agreement.

Many factors will lead to better information flows. Systems that repress civil society or the media will constrain information flows and learning (Tang and Tang 2018; Zweifel and Navia 2000). Highly federalized systems interrupt the signals transferred between voters and government officials (Fagan, Jones, and Wlezien 2017; Wlezien and Soroka 2012), and thus have weaker information flows. Systems where policymaking is directed by a dominant 
executive will have less deliberation, decreasing information flows (Fagan, Jones, and Wlezien 2017; Wlezien and Soroka 2012).

Finally, we should expect political and economic inequality to have a particularly severe impact on information flows. Economic inequality will reduce the supply of information flowing up from societies by reducing political participation and knowledge (Elkjær 2020; Erikson 2015; Houle 2018), as through further downstream policy feedback effects (Campbell 2012; HertelFernandez 2018; Houle 2018). Gender or racial political inequality can have similar demobilizing effects (Kenworthy 2009; Reich 2017). At the same time, inequality reduces responsiveness by elites to information from the mass public. Marginalized or poorer citizens will struggle to convince their governments to listen to their signals (Gilens and Page 2014; Miler 2018; Stuart N. Soroka and Wlezien 2008). Thus, systems with more political inequality will experience more policy disasters.

\section{Research Design}

I test these theories by using a quantitative historical analysis of countries from 19502016. As information flows decrease and veto players increase, I expect disasters to become more common. The unit of analysis is country-year in 70 countries across 60 years. ${ }^{1}$ Because the dependent variable below are counts of disasters in each country-year, I estimate disaster risk using a negative binomial model. ${ }^{2}$ I measured disasters using two independent conceptualizations: natural and technological disasters and financial crises.

\footnotetext{
${ }^{1}$ The sample is limited by the countries included the V-Dem 10.0 dataset. Many small countries or subnational units (such as British Overseas Territories) are excluded in the V-Dem data. Appendix Table 1 shows the countries and years included.

${ }^{2}$ Alpha is significant $(p<0.001)$ in all models, suggesting that negative binomial estimation is appropriate over a Poisson estimation.
} 
To measure natural and technological disasters, I use the EM-DAT dataset produced by the Centre for Research on Epidemiology of Disasters (Guha-Sapir 2020). These data describe disasters from all countries from 1950-present. Natural disasters cover the full range of potential natural causes of death, such as floods, earthquakes, volcanic activity, insect infestation, droughts and epidemic diseases. Technological disasters include industrial accidents such as oil spills and industrial fires, transportation accidents and infrastructure failures. I limit the data to disasters that cause more than 100 deaths. $^{3}$ These data are commonly used by scholars studying factors that cause specific types of disasters, such as landslides (Petley 2012), floods (Barredo 2009; Jonkman and Kelman 2005), earthquakes (Chang 2010) or climate change-related hazards (Fankhauser and McDermott 2014; Thomalla et al. 2006). A handful of social scientists have used the data as an independent variable to measure fiscal or economic changes after any disaster (Fomby, Ikeda, and Loayza 2009; Noy and Nualsri 2011; Shen and Hwang 2019; Toya and Skidmore 2007). However, the EM-DAT disasters data remain largely unexplored by social scientists as a dependent variable. I included all disasters which caused more than a hundred deaths. This constraint yields 1,010 disasters from 1960-2016. Annual disasters per country ranged from zero to thirteen.

To measure financial crises, I use data from Reinhart and Rogoff (2011). ${ }^{4}$ For each year, their dataset records whether a country experienced any of seven types of financial crisis. These include inflation crises, currency crises, banking crises, a sovereign debt default or a significant

\footnotetext{
${ }^{3}$ The EM-DAT data also include disasters that cause large property damage, but fewer deaths. Shen and Hwang (2019) find that property damage is overreported in rich countries relative to poor countries. Thus, I do not use property as a criterion for inclusion in the list of disasters. A future study focusing on rich countries, which tend to have fewer deaths overall, could incorporate these data.

${ }^{4}$ Herndon, Ash, and Pollin (2014) criticized a result from Reinhart and Rogoff (2011) that may have been driven by researcher error. The criticism refers to results examining the impact of high debt to GDP ratios on economic growth. It is not related to the data used here.
} 
domestic private debt crisis. The countries in the sample experienced 3,262 financial crises from 1950-2010. Annual financial crises per country ranged from zero to seven.

Because these data are independent conceptualizations of the dependent variable, we can make more generalized assessments of underlying policy disaster risk than we could from an analysis of each individually. Natural and technological disasters and financial crises are substantively different types of policy disasters. Financial crises are often caused by failures in banking, finance, fiscal, monetary and trade policy. Natural and technological disasters are caused by a diverse set of policy failures, ranging from flood mitigation to city planning to the regulation of industrial or workplace safety to agricultural policy. ${ }^{5}$ All systems will experience both types of disasters over long enough time horizons, but good public policy decision-making should decrease their frequency. If the explanatory variables have a similar relationship with risk of policy disasters in both conceptualizations, we can infer with measured confidence an understanding of the relationship between the explanatory variables and a generalized policy disaster process.

These dependent variables do not distinguish between disasters caused by negligence or mistakes. They measure the frequency of policy disasters in general. Future research is necessary to evaluate this article's predictions about how information flows and veto players should impact different types of policy disasters.

I draw explanatory variables from the Varieties of Democracy (V-Dem) 10.0 dataset (Coppedge et al. 2020). To measure regime type, I include the Regimes of the World categorical variables from Lührmann, Tannenberg, and Lindberg (2018). These data divide countries into

\footnotetext{
${ }^{5} \mathrm{~A}$ key weakness of these data is an inability to account for geography. Countries are exposed to very different risks of natural disasters due to geography. While these differences are somewhat balanced out by both the inclusion of technological disasters and many types of natural disasters, no data currently exists to account for all differences in natural disaster risk exposure.
} 
four categories: closed autocracies, electoral autocracies, electoral democracies, and liberal democracies. They are derived from other indices in the V-Dem dataset. I expect electoral democracies and autocracies to have higher disaster risk than closed autocracies, which will have higher disaster risk than liberal democracies. Models 1 and 2 (see Figure 2) estimate the following equation, modeling each $i$ country's disaster risk at each time $t$ :

\section{Equation 1: Policy Disaster Risk and Regime Type}

$$
\text { Risk }_{i t}=\propto+\text { ElecDem }_{i t}+\text { ElecAut }_{i t}+\text { ClosedAut }_{i t}+\text { Controls }_{i t}+e
$$

I also use various V-Dem indices to measure information flows and veto players in each country over time. To measure information flows, I include five independent variables. The first is an index of egalitarian democracy (Coppedge et al. 2020). As the index increases, political power in the country is distributed more equitably among racial, gender, social group or class lines. As societies become more egalitarian, disaster risk will decrease, as policymakers receive and process more information from the full spectrum of society. Next, I include indexes measuring the suppression of civil society and media censorship (Pemstein et al. 2018). As each of these indexes increases, disaster risk will increase as governments constrain information flows. Next, I included an index of federalism, where a higher score indicates greater autonomy for subnational units in making policy (Coppedge et al. 2020). As federalism increases, disaster risk will increase as signals from the public are confused or misdirected. Finally, I include an index of presidentialism, where a higher score indicates that the executive controls more political power in the country (Sigman and Lindberg 2018). I expect these systems to higher policy 
disaster risk resulting from weaker information flows, as fewer decision-makers deliberate on policy decisions (Fagan, Jones, and Wlezien 2017).

To measure veto players, I include three variables. The first is a binary variable coded=1 if a system has two empowered chambers in its legislature. ${ }^{6}$ I expect bicameral systems to have greater disaster risk as they have additional veto players. The second is the independence of the legislature from the executive branch, measured by the V-Dem Legislative Constraints on the Executive index. The index increases as the legislature is better able to investigate, question, or exercise oversight over the executive branch. I expect disaster risk to increase in these systems as legislative independence increases veto players in the system. Finally, I measure the degree to which the legislature and executive are one unified decision maker using an index of the legislature's practical ability to remove the executive (Teorell and Lindberg 2019). A higher score indicates that a legislature has fewer barriers to remove an executive. I expect these parliamentary systems to have lower disaster risk when compared with systems with more independent executives, as the executive and legislature are more likely to function as one player.

\section{Equation 2: Policy Disaster Risk and Information Flows and Veto Players}

$$
\begin{aligned}
\text { Risk }_{i t}=\propto+ & \text { Egalitarianism }_{i t}+\text { CivSocRepress }_{i t}+\text { MediaCensorship }_{i t} \\
& + \text { Federalism }_{i t}+\text { Presidentialism }_{i t}+\text { Bicamerialism }_{i t} \\
& + \text { Parliamentary }_{i t}+\text { LegConstraints }_{i t}+e
\end{aligned}
$$

Finally, I include three control variables. First, I include logged per capita income in all models. Richer countries should suffer fewer natural and technological disasters and financial

\footnotetext{
${ }^{6}$ A system with only one chamber is coded=0. For systems with multiple chambers, I used the V-Dem's dominant chamber index, where a negative score indicates that the lower chamber is dominate, a higher score indicates that the upper chamber is dominate and zero indicates if the chambers are equally balanced (Pemstein et al. 2018). The bicameral variable was coded $=1$ if the index is between -0.5 and 0.5 .
} 
crises. Second, I include year dummy variables in all models. ${ }^{7}$ Time dummies help to account for events that expose many countries to additional risk at the same time, such as a global or regional financial crisis or an international natural disaster. They also control for change in disaster risk over time, such as increased risk of flooding due to sea level rise or climate change. I also include the country's logged population in just the disaster models. Larger countries will have more natural and technological disasters because more people are at risk at any given time of a disaster. Thus, the corresponding model must control for population. However, there is no similar additional risk in large or small nations due to financial crisis, so I do not control for population in those models.

\section{Results}

Table 1 shows the results of the two negative binominal models estimated using Equation $1 .^{8}$ Because the four binary regime type variables are mutually exclusive, liberal democracy is excluded as the reference term. The coefficients can be interpreted as the disaster incidence rate ratio in each regime type relative to liberal democracies. Closed autocracies do not experience significantly more natural and technological disasters $(\mathrm{p}=0.283)$ but experience $60 \%$ more financial crisis $(\mathrm{p}<0.001)$. Electoral autocracies experience $75 \%$ more natural and technological disasters $(\mathrm{p}<0.001)$ and $100 \%$ more financial crises $(\mathrm{p}<0.001)$. Electoral democracies experience $140 \%$ more natural and technological disasters $(\mathrm{p}<0.001)$ and $105 \%$ more financial crises $(\mathrm{p}<.001)$. Overall, these results provide evidence to support the prediction that liberal democracies have a strong advantage over electoral autocracies and democracies in preventing

\footnotetext{
${ }^{7}$ I show models without the year dummies in Appendix Tables 2 and 3. No results change in terms of significance or direction.

${ }^{8}$ The alpha disturbance term in each model rejects the null hypothesis $(p<.001)$, indicating that negative binominal estimation is appropriate over Poisson estimation.
} 
disasters. Closed autocracies experience fewer disasters than electoral democracy and autocracies. Further research is needed to investigate the mixed result in closed autocracies relative to liberal democracies.

Table 1: Negative Binomial Estimation of the Risk of Policy Disasters, Governing Systems.

\begin{tabular}{lll}
\hline \multicolumn{1}{c}{ Independent Variables } & \multicolumn{1}{c}{$\begin{array}{c}\text { Financial } \\
\text { Crises }\end{array}$} & $\begin{array}{c}\text { Natural and } \\
\text { Technological Disasters }\end{array}$ \\
\hline Closed Autocracy & $1.56^{* * *}$ & 1.15 \\
& $(0.12)$ & $(0.15)$ \\
Electoral Autocracy & $1.76^{* * *}$ & $1.60^{* * *}$ \\
& $(0.15)$ & $(0.20)$ \\
Electoral Democracy & $2.01^{* * *}$ & $1.67^{* * *}$ \\
& $(0.14)$ & $(0.20)$ \\
Per Capita Income & & \\
(Logged) & 0.97 & $0.75^{* * *}$ \\
& $(0.03)$ & 0.03 \\
Population (Logged) & & $2.12^{* * *}$ \\
& & $(0.05)$ \\
\hline Alpha & $0.16^{* * *}$ & $0.45^{* * *}$ \\
\hline $\mathrm{n}$ & 4,215 & 4,022 \\
\hline
\end{tabular}

Reference term is liberal democracy. All models include year dummy variables. Incident rate ratio estimates. An estimate above 1.00 indicates a greater than average risk of the successes at each time. An estimate below 1.00 indicates a lower risk. Standard errors in parentheses. $* p<0.05 * * p<.01 * * * p<.001$.

Table 2 shows the results of the two models estimated using Equation 2. ${ }^{9}$ Because all of the independent variables other than bicameralism are indices, they do not have a clear substantive interpretation other than their direction and statistical significance. More egalitarian systems experience both fewer natural and technological disasters $(\mathrm{p}<.001)$ and financial crises

\footnotetext{
${ }^{9}$ No results change in either direction or significance when year dummies are replaced with a trend variable or when no the model contains no time variable.
} 
$(p=0.014)$. Systems that repress civil society suffer significantly more natural and technological disasters $(\mathrm{p}=0.001)$ but not financial crises $(\mathrm{p}=0.616)$. More federalized systems and systems that censor media experience more of both types of disasters $(\mathrm{p}<.001)$. More presidentialist systems experience more financial crises $(\mathrm{p}<.001)$ but not more natural and technological disasters $(\mathrm{p}=0.251)$. Taken together, these results suggest that information flows have a strong impact on policy disasters generally. The null or mixed results found comparing civil society repression and presidentialism may be related to the tradeoff between veto players and information flows. Civil society can function as an informal veto player. Executives who control their political system can eliminate veto players. These mixed results deserve further study.

There is weaker evidence to support the prediction that fewer veto players leader to greater disaster risk. Bicameral systems do not experience more natural and technological disasters $(\mathrm{p}=0.822)$ nor financial crises $(\mathrm{p}=0.323)$. Parliamentary systems experience fewer natural and technological disasters $(\mathrm{p}=0.001)$ and financial crises $(\mathrm{p}<.001)$. Systems where the legislature is empowered to serve as a check on the executive through oversight or investigation experience more financial crises $(\mathrm{p}<0.001)$ but not natural and technological disasters $(\mathrm{p}=0.492)$.

Overall, these results strongly suggest that there is an underlying policy disaster process that is partially explained by the models. Both types of policy disasters have a similar relationship to the independent variables in both models. They are both less likely when information flows are high. The results are more mixed, but on both appear to be less likely when veto players are low. Because the results are so similar, they suggest the results represent a generalized explanation of a policy disaster process. 
Table 2: Negative Binomial Estimation of the Risk of Policy Disasters, Veto Players and Information Flows

\begin{tabular}{lcc}
\hline \multicolumn{1}{c}{ Independent Variables } & $\begin{array}{c}\text { Financial } \\
\text { Crises }\end{array}$ & $\begin{array}{c}\text { Natural and } \\
\text { Technological } \\
\text { Disasters }\end{array}$ \\
\hline Information Flows & $0.61^{* *}$ & $0.06^{* * *}$ \\
Egalitarian Democracy Index & $(0.12)$ & $(0.02)$ \\
Civil Society Repression Index & 0.97 & $1.14^{* *}$ \\
& $(0.03)$ & $(0.06)$ \\
Media Censorship Index & $1.08^{* *}$ & $1.32^{* * *}$ \\
& $(0.03)$ & $(0.07)$ \\
Federalism Index & $1.68^{* * *}$ & $1.77^{* * *}$ \\
& $(0.13)$ & $(0.22)$ \\
Presidentialism Index & $1.85^{* *}$ & 1.14 \\
& $(0.37)$ & $(0.38)$ \\
Veto Players & & \\
Parliamentary Index & $0.74 * * *$ & $0.69 * *$ \\
Bicameral Legislature & $(0.05)$ & $(0.08)$ \\
& 1.11 & 0.99 \\
Legislative Constraints on the & $(0.08)$ & $(0.11)$ \\
Executive & & \\
& $1.69 * *$ & 0.85 \\
Demographics & $(0.29)$ & $(0.27)$ \\
Per Capita Income (Logged) & & \\
Population (Logged) & $0.80^{*}$ & $0.77 * * *$ \\
& $(0.03)$ & $(0.03)$ \\
\hline Alpha & & $2.12^{* * *}$ \\
$\mathrm{n}$ & $0.15^{* * * *}$ & $(0.05)$ \\
\hline
\end{tabular}

All models contain year dummy variables. Incident rate ratio estimates. An estimate above 1.00 indicates a greater than average risk of the successes at each time period. An estimate below 1.00 indicates a lower risk. Standard errors in parentheses. $* \mathrm{p}<0.05 * *$ $\mathrm{p}<.01 * * * \mathrm{p}<.001$.

\section{Discussion}

This paper aimed to start a conversation about the generalized causes of policy disasters. These seismic events can reshape a country's political and economic landscape and are affected by political institutions, but they are rarely examined by political science. In this paper, I argued that punctuated equilibrium theory provides a general theory of government information 
processing and error accumulation, we can use it to generate testable hypotheses about how political institutions might increase the risk of policy disasters. Systems with many veto players and weak information flows tend to be less efficient information processes. Thus, I hypothesized that governing systems with both will likely be at higher risk of policy disasters.

I tested these hypotheses using data on financial crises and natural and technological disasters over six decades. In a broad analysis of regime types, I found that electoral democracies and autocracies suffer the most policy disasters, while liberal democracies suffer the fewest. These results align well with the literature on punctuated equilibrium theory and regimes, which consistently find that democracies outperform authoritarian regimes, and the literature on democracy and human development, which finds that established democracies mostly outperform authoritarian countries and transitional regimes. Notably, the results are similar for both models, despite using very different dependent variables. The remarkable congruence between these datasets suggests an underlying data generating process that increases risk of policy disasters. Liberal democracy's ability to avoid policy disasters may even account for its advantage over authoritarianism in economic growth and human development indicators that has somewhat puzzled economists.

As with any early conversation, there is much more to be said about policy disasters. This paper used a large-n research design over long time periods to examine the impact of political institutions on the risk of rare events. While this design has its advantages, it limits the data available to evaluate hypotheses to those available for many countries over decades. Future research designs could instead examine a cross section of systems responding to a common crisis, such as U.S. states. They could also explore other types of policy disasters. The COVID19 pandemic exposed every system on the planet to a common crisis at the same time. 
Researchers could explore how variation in policy outcomes are related to information flows and veto players. Furthermore, researchers could explore how slower-moving crises such as severe housing shortages or gun violence in U.S. states or disasters caused by failures to prepare for climate change. Finally, qualitative research designs could better identify the mechanisms creating intense failures, expand the types of policy disasters available for researchers, and harness interdisciplinary expertise. 
Appendix Table 1: Country-Years Included in Models

\begin{tabular}{|c|c|c|c|c|c|}
\hline Country & Financial Crises & Natural/Technological & Country & $\begin{array}{c}\text { Financial } \\
\text { Crises }\end{array}$ & Natural/Technological \\
\hline Algeria & $\begin{array}{l}1977-1990 ; \\
1993-2010\end{array}$ & 1977-1990; 1993-2016 & Japan & $1950-2010$ & $1960-2016$ \\
\hline Angola & $1975-2010$ & $1975-2016$ & Kenya & $1950-2010$ & $1960-2016$ \\
\hline Argentina & $\begin{array}{c}1950-1965 \\
1973-1975 \\
1983-2010\end{array}$ & $\begin{array}{c}1960-1965 ; 1973-1975 ; \\
1983-2016\end{array}$ & Malaysia & $\begin{array}{c}1950-1953 \\
1981-2010\end{array}$ & 1960-1968; 1972-2016 \\
\hline Australia & $1950-2010$ & $1960-2016$ & Mauritius & $1950-2010$ & $1960-2016$ \\
\hline Austria & $1950-2010$ & $1960-2016$ & Mexico & $1950-2010$ & $1960-2016$ \\
\hline Belgium & $1950-2010$ & $1960-2016$ & Morocco & $\begin{array}{l}1963-1965 \\
1970-2010\end{array}$ & $1963-1965 ; 1970-2016$ \\
\hline Bolivia & $1950-2010$ & 1960-1968; 1979-2016 & Netherlands & $1950-2010$ & 1960-2016 \\
\hline Brazil & $1950-2010$ & 1960-2016 & $\begin{array}{l}\text { New } \\
\text { Zealand }\end{array}$ & $1950-2010$ & 1960-2016 \\
\hline Bulgaria & $1950-2010$ & $1960-2016$ & Nicaragua & $\begin{array}{c}1950-1978 \\
1985-2010\end{array}$ & $1960-1971 ; 1973-2016$ \\
\hline Myanmar & $\begin{array}{l}1950-1962 ; \\
1974-1987\end{array}$ & $\begin{array}{c}\text { 1960-1962; 1974-1987; } \\
2011-2016\end{array}$ & Nigeria & $\begin{array}{c}1950-1965 \\
1979-1982 \\
1999-2010\end{array}$ & $\begin{array}{c}1960-1965 ; 1979-1982 ; \\
1999-2016\end{array}$ \\
\hline Canada & $1950-2010$ & $1960-2016$ & Norway & $1950-2010$ & $1960-2016$ \\
\hline Cen. African Rep. & $\begin{array}{l}1950-1963 ; \\
1987-2010\end{array}$ & 1960-1963; 1987-2016 & Panama & $\begin{array}{c}1950-1967 \\
1972-2010\end{array}$ & $1960-1967 ; 1972-2016$ \\
\hline Chile & $\begin{array}{l}1950-1972 \\
1990-2010\end{array}$ & 1960-1972; 1990-2016 & Paraguay & $\begin{array}{l}1950-1958 \\
1961-2010\end{array}$ & 1961-2016 \\
\hline China & $1954-2010$ & $1960-2016$ & Peru & $\begin{array}{c}1950-1967 \\
1980-2010\end{array}$ & 1960-1967; 1980-2016 \\
\hline Colombia & $1951-2010$ & $1960-2016$ & Philippines & $\begin{array}{l}1950-1971 \\
1978-2010\end{array}$ & 1960-1971; 1978-2016 \\
\hline Costa Rica & $1950-2010$ & 1960-2016 & Poland & $1950-2010$ & $1960-2016$ \\
\hline Denmark & $1950-2010$ & $1960-2016$ & Portugal & $\begin{array}{l}1950-1973 ; \\
1976-2010\end{array}$ & 1960-1973; 1976-2016 \\
\hline Dominican Rep. & $\begin{array}{c}1950-1962 \\
1965-2010\end{array}$ & 1960-1962; 1965-2016 & Romania & $1950-2010$ & $1960-2016$ \\
\hline Ecuador & $\begin{array}{l}1950-1969 \\
1980-2010\end{array}$ & 1960-1969; 1980-2016 & Russia & $1960-2010$ & $1960-2016$ \\
\hline Egypt & $\begin{array}{l}1950-1952 \\
1956-1957 \\
1959-1960 \\
1964-2010\end{array}$ & 1964-2010; 2015-2016 & Singapore & $1950-2010$ & $1960-2016$ \\
\hline El Salvador & $\begin{array}{c}1950-1978 ; \\
1985-2010\end{array}$ & $1962-1978 ; 1985-2016$ & South Africa & $1950-2010$ & 1960-2016 \\
\hline Finland & $1950-2010$ & 1960-2016 & South Korea & $1950-2010$ & $1960-2016$ \\
\hline France & $1950-2010$ & $1960-2016$ & Spain & $1950-2010$ & $1960-2016$ \\
\hline Germany & $1950-2010$ & 1960-2016 & Sri Lanka & $1950-2010$ & 1960-2016 \\
\hline Ghana & $\begin{array}{l}1951-1980 \\
1993-2010\end{array}$ & $\begin{array}{c}1960-1971 ; 1979-1980 ; \\
1993-2016\end{array}$ & Sweden & $1950-2010$ & $1960-2016$ \\
\hline Greece & $\begin{array}{l}1950-1966 \\
1974-2010\end{array}$ & 1960-1966; 1974-2016 & Switzerland & $1950-2010$ & 1960-2016 \\
\hline Guatemala & $\begin{array}{c}1950-1962 ; \\
1966-2010\end{array}$ & 1960-1962; 1966-2016 & Thailand & $\begin{array}{l}1950-1957 ; \\
1969-2010\end{array}$ & 1969-2016 \\
\hline Honduras & $\begin{array}{c}1950-1953 ; \\
1970-1971 ; \\
1981-2010\end{array}$ & 1970-1971; 1981-2016 & Tunisia & $1959-2010$ & 1960-2016 \\
\hline Hong Kong & $\mathrm{n} / \mathrm{a}$ & $1960-2016$ & Turkey & $\begin{array}{c}1950-1979 \\
1982-2010\end{array}$ & 1960-1979; 1982-2016 \\
\hline Hungary & $1950-2010$ & $1960-2016$ & UK & $1950-2010$ & $1960-2016$ \\
\hline Iceland & $1950-2010$ & 1960-2016 & $\begin{array}{l}\text { United } \\
\text { States }\end{array}$ & $1950-2010$ & $1960-2016$ \\
\hline India & $1950-2010$ & $1960-2016$ & Uruguay & $\begin{array}{c}1950-1972 ; \\
1984-2010\end{array}$ & 1960-1972; 1984-2016 \\
\hline Ireland & $1950-2010$ & $1960-2016$ & Venezuela & $1958-2010$ & $1960-2016$ \\
\hline Italy & $1950-2010$ & 1960-2016 & Zambia & $1950-2010$ & 1960-2016 \\
\hline Ivory Coast & $\begin{array}{l}1950-1998 ; \\
2001-2010\end{array}$ & 1960-1998; 2001-2016 & Zimbabwe & $1950-2010$ & $1960-2016$ \\
\hline
\end{tabular}


Appendix Table 1: Negative Binomial Estimation of the Risk of Policy Disasters, Governing Systems

\begin{tabular}{|c|c|c|}
\hline Independent Variables & $\begin{array}{c}\text { Financial } \\
\text { Crises }\end{array}$ & $\begin{array}{c}\text { Natural and } \\
\text { Technological Disasters }\end{array}$ \\
\hline \multirow[t]{2}{*}{ Closed Autocracy } & $1.62 * * *$ & 1.12 \\
\hline & $(0.13)$ & $(0.15)$ \\
\hline \multirow[t]{2}{*}{ Electoral Autocracy } & $2.00 * * *$ & $1.58 * * *$ \\
\hline & $(0.15)$ & $(0.20)$ \\
\hline \multirow[t]{2}{*}{ Electoral Democracy } & $2.40 * * *$ & $1.67 * * *$ \\
\hline & $(0.17)$ & $(0.20)$ \\
\hline \multicolumn{3}{|l|}{ Per Capita Income } \\
\hline \multirow[t]{2}{*}{ (Logged) } & $1.10 * *$ & $0.75^{* * *}$ \\
\hline & $(0.03)$ & 0.03 \\
\hline \multirow[t]{2}{*}{ Population (Logged) } & & $2.15^{* * *}$ \\
\hline & & $(0.05)$ \\
\hline Alpha & $0.55 * * *$ & $0.45 * * *$ \\
\hline$n$ & 4,215 & 4,022 \\
\hline \multicolumn{3}{|c|}{$\begin{array}{l}\text { Incident rate ratio estimates. An estimate above } 1.00 \text { indicates a } \\
\text { greater than average risk of the successes at each time. An estimate } \\
\text { below } 1.00 \text { indicates a lower risk. Standard errors in parentheses. } \\
\qquad p<0.05^{* *} p<.01 * * * p<.001 .\end{array}$} \\
\hline
\end{tabular}


Appendix Table 2: Negative Binomial Estimation of the Risk of Policy Disasters, Veto Players and Information Flows

\begin{tabular}{|c|c|c|}
\hline Independent Variables & $\begin{array}{l}\text { Financial } \\
\text { Crises }\end{array}$ & $\begin{array}{c}\text { Natural and } \\
\text { Technological } \\
\text { Disasters }\end{array}$ \\
\hline \multicolumn{3}{|l|}{ Information Flows } \\
\hline Egalitarian Democracy Index & $\begin{array}{l}0.59 * \\
(0.13)\end{array}$ & $\begin{array}{c}0.07 * * * \\
(0.02)\end{array}$ \\
\hline Civil Society Repression Index & $\begin{array}{c}1.02 \\
(0.03)\end{array}$ & $\begin{array}{c}1.17 * * \\
(0.06)\end{array}$ \\
\hline Media Censorship Index & $\begin{array}{c}1.13^{* * * *} \\
(0.04)\end{array}$ & $\begin{array}{c}1.37 * * * \\
(0.08)\end{array}$ \\
\hline Federalism Index & $\begin{array}{c}1.53 * * * \\
(0.13)\end{array}$ & $\begin{array}{c}1.66 * * * \\
(0.21)\end{array}$ \\
\hline Presidentialism Index & $\begin{array}{c}2.86 * * \\
(0.64)\end{array}$ & $\begin{array}{c}1.48 \\
(0.51)\end{array}$ \\
\hline \multicolumn{3}{|l|}{ Veto Players } \\
\hline Parliamentary Index & $\begin{array}{c}0.71 * * * \\
(0.05)\end{array}$ & $\begin{array}{l}0.68 * * \\
(0.08)\end{array}$ \\
\hline Bicameral Legislature & $\begin{array}{c}0.93 \\
(0.03)\end{array}$ & $\begin{array}{c}0.97 \\
(0.11)\end{array}$ \\
\hline \multicolumn{3}{|l|}{ Legislative Constraints on the } \\
\hline Executive & $\begin{array}{l}1.79 * * \\
(0.35)\end{array}$ & $\begin{array}{c}0.80 \\
(0.26)\end{array}$ \\
\hline \multicolumn{3}{|l|}{ Demographics } \\
\hline Per Capita Income (Logged) & $\begin{array}{l}0.92 * \\
(0.03)\end{array}$ & $\begin{array}{c}0.76 * * * \\
(0.03)\end{array}$ \\
\hline Population (Logged) & & $\begin{array}{c}2.13 * * * \\
(0.04) \\
\end{array}$ \\
\hline Alpha & $0.55 * * *$ & $0.20 * *$ \\
\hline $\mathrm{n}$ & 3,860 & 3,717 \\
\hline
\end{tabular}

An estimate above 1.00 indicates a greater than average risk of the successes at each time period. An estimate below 1.00 indicates a lower risk. Standard errors in parentheses. * $\mathrm{p}<0.05 * * \mathrm{p}<.01 * * *$ $\mathrm{p}<.001$. 


\section{References}

Acemoglu, Daron, Suresh Naidu, Pascual Restrepo, and James A. Robinson. 2019. “Democracy Does Cause Growth." Journal of Political Economy 127(1): 47-100.

Albright, Elizabeth A. 2011. "Policy Change and Learning in Response to Extreme Flood Events in Hungary: An Advocacy Coalition Approach: Albright: Policy Change and Learning." Policy Studies Journal 39(3): 485-511.

Barredo, J. I. 2009. "Normalised Flood Losses in Europe: 1970-2006." Natural Hazards and Earth System Sciences 9(1): 97-104.

Barro, Robert J. 1996. "Democracy and Growth." Journal of Economic Growth 1(1): 1-27.

Baumgartner, Frank R. et al. 2009. Lobbying and Policy Change: Who Wins, Who Loses, and Why. University of Chicago Press.

- - . 2017. "Budgetary Change in Authoritarian and Democratic Regimes." Journal of European Public Policy 24(6): 792-808.

Baumgartner, Frank R., and Bryan D. Jones. 1993. Agendas and Instability in American Politics. Chicago: University of Chicago Press.

- - . 2015. The Politics of Information: Problem Definition and the Course of Public Policy in America. University of Chicago Press.

Bevan, Shaun, and Anne Rasmussen. 2017. "When Does Government Listen to the Public? Voluntary Associations and Dynamic Agenda Representation in the United States." Policy Studies Journal 00(00): 1-22.

Bizzarro, Fernando et al. 2018. "Party Strength and Economic Growth." World Politics 70(2): 275-320.

Bovens, Mark, and Paul 't Hart. 2016. "Revisiting the Study of Policy Failures." Journal of European Public Policy 23(5): 653-66.

Boydstun, Amber E. 2013. Making the News: Politics, the Media, and Agenda Setting. Chicago ; London: The University of Chicago Press.

Breunig, Christian, and Chris Koski. 2009. "Punctuated Budgets and Governors' Institutional Powers." American Politics Research 37(6): 1116-38.

Brummer, Klaus. 2016. “'Fiasco Prime Ministers': Leaders' Beliefs and Personality Traits as Possible Causes for Policy Fiascos." Journal of European Public Policy 23(5): 702-17. 
Bulut, Alper T., and Tevfik Murat Yildirim. 2019. "The Dynamics of Policy Agenda, Issue Diversity, and Policy Change in Democratic and Non-Democratic Times." In Political Stability, Democracy and Agenda Dynamics in Turkey, , 131-53.

Campbell, Andrea Louise. 2012. "Policy Makes Mass Politics." Annual Review of Political Science 15(1): 333-51.

Chan, Kwan Nok, and Shiwei Fan. 2020. "Friction and Bureaucratic Control in Authoritarian Regimes." Regulation \& Governance. http://doi.wiley.com/10.1111/rego.12310 (May 14, 2020).

Chan, Kwan Nok, and Shuang Zhao. 2016. "Punctuated Equilibrium and the Information Disadvantage of Authoritarianism: Evidence from the People's Republic of China: Punctuated Equilibrium Under Authoritarianism." Policy Studies Journal 44(2): 134-55.

Chang, Stephanie E. 2010. "Urban Disaster Recovery: A Measurement Framework and Its Application to the 1995 Kobe Earthquake." Disasters 34(2): 303-27.

Cho, Ki Woong, and Kyujin Jung. 2019. "Illuminating the Sewol Ferry Disaster Using the Institutional Model of Punctuated Equilibrium Theory." The Social Science Journal 56(2): 288-303.

Crow, Deserai A. et al. 2018. "Do Disasters Lead to Learning? Financial Policy Change in Local Government: Do Disasters Lead to Learning?" Review of Policy Research 35(4): 564-89.

Dunleavy, Patrick. 1995. "Policy Disasters: Explaining the UK's Record." Public Policy and Administration 10(2): 52-70.

Dunlop, Claire A. 2017. "Policy Learning and Policy Failure: Definitions, Dimensions and Intersections." Policy \& Politics 45(1): 3-18.

Dunlop, Claire A., Scott James, and Claudio M. Radaelli. 2020. "Can't Get No Learning: The Brexit Fiasco through the Lens of Policy Learning." Journal of European Public Policy 27(5): 703-22.

Elkjær, Mads Andreas. 2020. "What Drives Unequal Policy Responsiveness? Assessing the Role of Informational Asymmetries in Economic Policy-Making." Comparative Political Studies 53(14): 2213-45.

Epp, Derek A. 2018. The Structure of Policy Change. Chicago ; London: The University of Chicago Press.

Erikson, Robert S. 2015. "Income Inequality and Policy Responsiveness." Annual Review of Political Science 18(1): 11-29. 
Escudero, José Carlos. 1981. "Democracy, Authoritarianism, and Health in Argentina." International Journal of Health Services 11(4): 559-72.

Fagan, E. J., Bryan D. Jones, and Christopher Wlezien. 2017. "Representative Systems and Policy Punctuations." Journal of European Public Policy 24(6): 809-31.

Fankhauser, Samuel, and Thomas K. J. McDermott. 2014. “Understanding the Adaptation Deficit: Why Are Poor Countries More Vulnerable to Climate Events than Rich Countries?" Global Environmental Change 27: 9-18.

Fomby, Thomas, Yuki Ikeda, and Norman Loayza. 2009. The Growth Aftermath Of Natural Disasters. The World Bank. http://elibrary.worldbank.org/doi/book/10.1596/1813-94505002 (June 25, 2020).

Gerring, John, Philip Bond, William T. Barndt, and Carola Moreno. 2005. "Democracy and Economic Growth: A Historical Perspective." World Politics 57(3): 323-64.

Gilens, Martin, and Benjamin I. Page. 2014. "Testing Theories of American Politics: Elites, Interest Groups, and Average Citizens." Perspectives on Politics 12(3): 564-81.

Herndon, T., M. Ash, and R. Pollin. 2014. “Does High Public Debt Consistently Stifle Economic Growth? A Critique of Reinhart and Rogoff." Cambridge Journal of Economics 38(2): 257-79.

Hertel-Fernandez, Alexander. 2018. "Policy Feedback as Political Weapon: Conservative Advocacy and the Demobilization of the Public Sector Labor Movement." Perspectives on Politics 16(2): 364-79.

Houle, Christian. 2018. "Does Economic Inequality Breed Political Inequality?" Democratization 25(8): 1500-1518.

Jones, Bryan D. 2001. Politics and the Architecture of Choice: Bounded Rationality and Governance. University of Chicago Press.

- - . 2009. "A General Empirical Law of Public Budgets: A Comparative Analysis." American Journal of Political Science 53(4): 855-73.

Jones, Bryan D., and Frank R. Baumgartner. 2005. The Politics of Attention: How Government Prioritizes Problems. University of Chicago Press.

Jones, Bryan D., Derek A. Epp, and Frank R. Baumgartner. 2019. “Democracy, Authoritarianism, and Policy Punctuations." International Review of Public Policy 1(1): 7-26.

Jones, Bryan D., Herschel F. Thomas, and Michelle Wolfe. 2014. "Policy Bubbles: Policy Bubbles." Policy Studies Journal 42(1): 146-71. 
Jonkman, Sebastiaan N., and Ilan Kelman. 2005. "An Analysis of the Causes and Circumstances of Flood Disaster Deaths: An Analysis of the Causes and Circumstances of Flood Disaster Deaths." Disasters 29(1): 75-97.

Keefer, Philip. 2007. "Clientelism, Credibility, and the Policy Choices of Young Democracies." American Journal of Political Science 51(4): 804-21.

Kenworthy, Tom. 2009. "A Renewable Energy Standard: The Proof Is in the States." Center for American Progress.

https://www.americanprogress.org/issues/green/news/2009/05/19/6027/a-renewableenergy-standard-the-proof-is-in-the-states/ (February 11, 2020).

Lam, Wai Fung, and Kwan Nok Chan. 2015. "How Authoritarianism Intensifies Punctuated Equilibrium: The Dynamics of Policy Attention in Hong Kong: Policy Dynamics in Hong Kong." Governance 28(4): 549-70.

Lührmann, Anna, Marcus Tannenberg, and Staffan I. Lindberg. 2018. "Regimes of the World (RoW): Opening New Avenues for the Comparative Study of Political Regimes." Politics and Governance 6(1): 60.

Maor, Moshe. 2014. "Policy Bubbles: Policy Overreaction and Positive Feedback: Policy Bubbles." Governance 27(3): 469-87.

May, Peter J., Joshua Sapotichne, and Samuel Workman. 2009. "Widespread Policy Disruption and Interest Mobilization." Policy Studies Journal 37(4): 793-815.

McConnell, Allan. 2016. "A Public Policy Approach to Understanding the Nature and Causes of Foreign Policy Failure." Journal of European Public Policy 23(5): 667-84.

McConnell, Allan, Anika Gauja, and Linda Courtenay Botterill. 2008. "Policy Fiascos, Blame Management and AWB Limited: The Howard Government's Escape from the Iraq Wheat Scandal." Australian Journal of Political Science 43(4): 599-616.

McCubbins, Mathew D., and Thomas Schwartz. 1984. "Congressional Oversight Overlooked: Police Patrols versus Fire Alarms." American Journal of Political Science 28(1): 165-79.

McGuire, James W. 2013. "Political Regime and Social Performance." Contemporary Politics 19(1): 55-75.

Miler, Kristina C. 2018. Poor Representation: Congress and the Politics of Poverty in the United States. Cambridge, United Kingdom ; New York, NY: Cambridge University Press.

Miller, Michael K. 2015. "Electoral Authoritarianism and Human Development." Comparative Political Studies 48(12): 1526-62. 
Nair, Sreeja, and Michael Howlett. 2017. "Policy Myopia as a Source of Policy Failure: Adaptation and Policy Learning under Deep Uncertainty." Policy \& Politics 45(1): 10318.

Nohrstedt, Daniel. 2008. "The Politics of Crisis Policymaking: Chernobyl and Swedish Nuclear Energy Policy." Policy Studies Journal 36(2): 257-78.

Nohrstedt, Daniel, and Christopher M. Weible. 2010. "The Logic of Policy Change after Crisis: Proximity and Subsystem Interaction." Risk, Hazards \& Crisis in Public Policy 1(2): 1-32.

Noy, Ilan, and Aekkanush Nualsri. 2011. "Fiscal Storms: Public Spending and Revenues in the Aftermath of Natural Disasters." Environment and Development Economics 16(1): 11328.

Olson, Mancur. 1993. "Dictatorship, Democracy, and Development." American Political Science Review 87(3): 567-76.

Oppermann, Kai, and Alexander Spencer. 2016a. "Studying Fiascos: Bringing Public and Foreign Policy Together." Journal of European Public Policy 23(5): 643-52.

- - . 2016b. "Telling Stories of Failure: Narrative Constructions of Foreign Policy Fiascos." Journal of European Public Policy 23(5): 685-701.

Or, Nick H. K. 2019. "How Policy Agendas Change When Autocracies Liberalize: The Case of Hong Kong, 1975-2016." Public Administration 97(4): 926-41.

Park, Angela Y. S., and Joshua Sapotichne. 2019. "Punctuated Equilibrium and Bureaucratic Autonomy in American City Governments." Policy Studies Journal n/a(n/a). https://onlinelibrary.wiley.com/doi/abs/10.1111/psj.12333 (May 23, 2020).

Pemstein, Daniel et al. 2018. "The Varieties of Democracy Measurement Model: Latent Variable Analysis for Cross-National and Cross-Temporal Expert-Coded Data." V-Dem Institute Working Paper (21). https://www.v-dem.net/media/filer_public/5a/23/5a231d27-8f144b87-9a27-1536d6a2e482/v-dem_working_paper_2018_21_3.pdf.

Petley, David. 2012. "Global Patterns of Loss of Life from Landslides." Geology 40(10): 927-30.

Reich, Michael. 2017. Racial Inequality: A Political-Economic Analysis. Princeton University Press.

Reinhart, Carmen M., and Kenneth S. Rogoff. 2011. This Time Is Different: Eight Centuries of Financial Folly. Reprint edition. Princeton: Princeton University Press.

Robinson, Scott E. 2004. "Punctuated Equilibrium, Bureaucratization, and Budgetary Changes in Schools." Policy Studies Journal 32(1): 25-39. 
Sebők, Miklós, and Tamás Berki. 2018. "Punctuated Equilibrium in Democracy and Autocracy: An Analysis of Hungarian Budgeting between 1868 and 2013." European Political Science Review 10(4): 589-611.

Sen, Amartya. 1981. Poverty and Famines: An Essay on Entitlement and Deprivation. Oxford : New York: Clarendon Press; Oxford University Press.

Shen, Guoqiang, and Seong Nam Hwang. 2019. "Spatial-Temporal Snapshots of Global Natural Disaster Impacts Revealed from EM-DAT for 1900-2015." Geomatics, Natural Hazards and Risk 10(1): 912-34.

Sigman, Rachel, and Staffan Lindberg. 2018. Neopatrimonialism and Democracy: An Empirical Investigation of Africa's Political Regimes.

https://www.researchgate.net/deref/http\%3A\%2F\%2Fdx.doi.org\%2F10.2139\%2Fssrn.30 66654?_sg\%5B0\%5D=2ibV1pYls7ASVXz4IxLN9Ru1mGwh_rGVrWX26NojDHWdsPdPCztoUOW3bihevgH2xpX9G2oeg1DZP3WGpsetmug.DUghF7XbX9hcYhS8NoAE8hKic3EhHM_ju_uCqIHwaP5ol173mPDpUgRTd D4IfXRxGPhDRJFeka28PO4JdzjPeA.

Soroka, Stuart N., and Christopher Wlezien. 2008. "On the Limits to Inequality in Representation." PS: Political Science and Politics 41(2): 319-27.

Soroka, Stuart Neil, and Christopher Wlezien. 2010. Degrees of Democracy: Politics, Public Opinion, and Policy. Cambridge ; New York: Cambridge University Press.

Stone, Deborah A. 1989. "Causal Stories and the Formation of Policy Agendas." Political Science Quarterly 104(2): 281-300.

Stone, Diane. 2017. "Understanding the Transfer of Policy Failure: Bricolage, Experimentalism and Translation." Policy \& Politics 45(1): 55-70.

Tang, Rui, and Shiping Tang. 2018. “Democracy's Unique Advantage in Promoting Economic Growth: Quantitative Evidence for a New Institutional Theory." Kyklos 71(4): 642-66.

Teorell, Jan, and Staffan I. Lindberg. 2019. "Beyond Democracy-Dictatorship Measures: A New Framework Capturing Executive Bases of Power, 1789-2016." Perspectives on Politics 17(1): 66-84.

Thomalla, Frank et al. 2006. "Reducing Hazard Vulnerability: Towards a Common Approach between Disaster Risk Reduction and Climate Adaptation: Reducing Hazard Vulnerability." Disasters 30(1): 39-48.

Toya, Hideki, and Mark Skidmore. 2007. "Economic Development and the Impacts of Natural Disasters." Economics Letters 94(1): 20-25. 
Treisman, Daniel. 2020. "Democracy by Mistake: How the Errors of Autocrats Trigger Transitions to Freer Government." American Political Science Review: 1-19.

Tsebelis, George. 2002. Veto Players: How Political Institutions Work. Princeton, N.J: Princeton University Press.

Tuchman, Barbara W. 1985. The March of Folly: From Troy to Vietnam. New York: Random House Trade Paperbacks.

Williams, Russell Alan. 2009. "Exogenous Shocks in Subsystem Adjustment and Policy Change: The Credit Crunch and Canadian Banking Regulation." Journal of Public Policy 29(1): 2953.

Wlezien, Christopher, and Stuart N. Soroka. 2012. "Political Institutions and the Opinion-Policy Link." West European Politics 35(6): 1407-32.

Wolfe, Michelle. 2012. "Putting on the Brakes or Pressing on the Gas? Media Attention and the Speed of Policymaking: Wolfe: Media Attention and the Speed of Policymaking." Policy Studies Journal 40(1): 109-26.

Zweifel, Thomas D., and Patricio Navia. 2000. "Democracy, Dictatorship, and Infant Mortality." Journal of Democracy 11(2): 99-114. 